\title{
Truck Driver Dies after Being Struck by Semi-Trailer Truck In Trailer Lot of Customer Yard
}
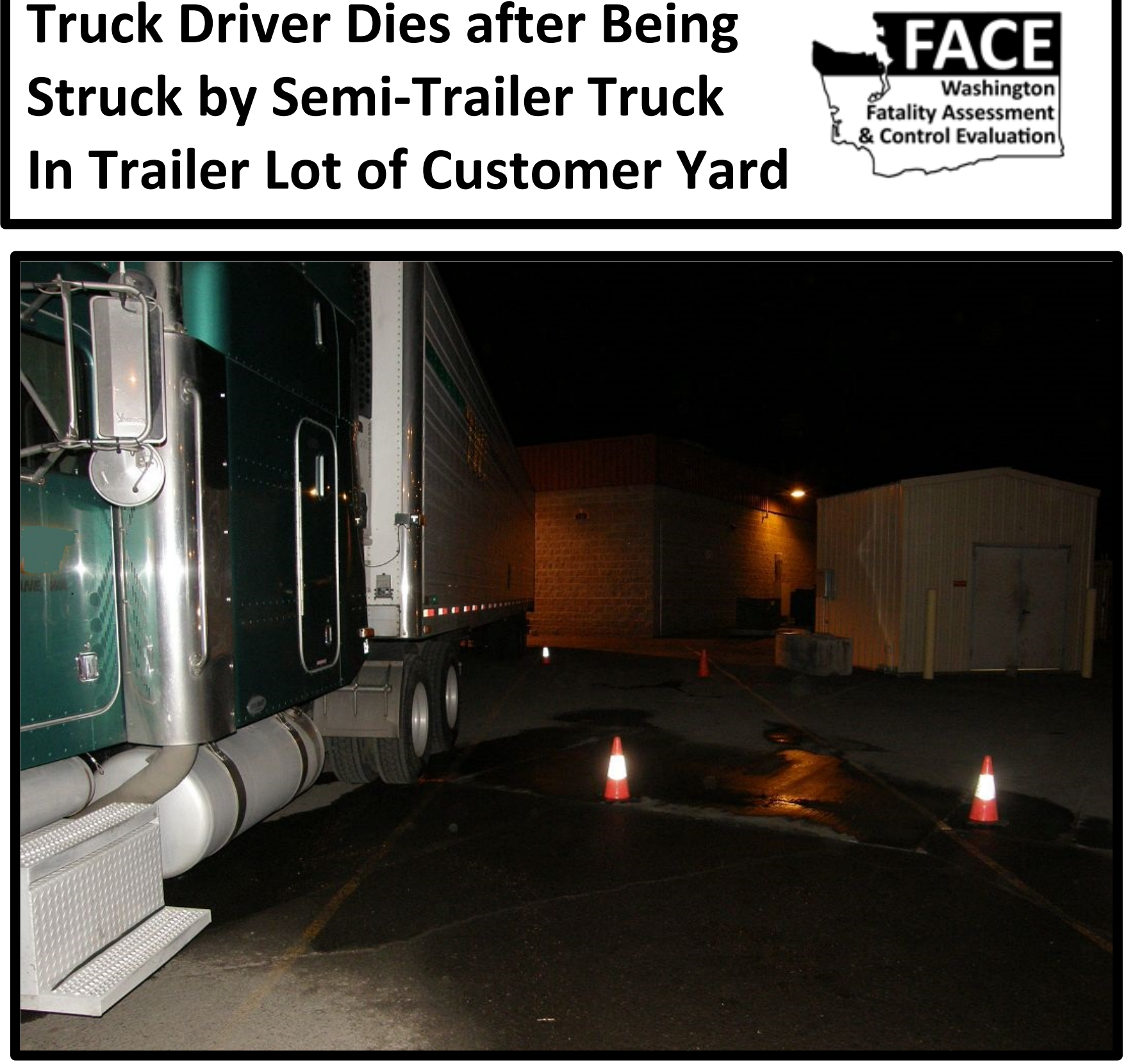

Investigation: \# 11WA012

Release Date: November 16, 2015

SHARP Report: \# 52-35-2015 
TABLE OF CONTENTS

CONTENTS

PAGE

$\begin{array}{ll}\text { SUMMARY } & 3\end{array}$

$\begin{array}{ll}\text { RECOMMENDATIONS } & 4\end{array}$

$\begin{array}{ll}\text { INTRODUCTION } & 5\end{array}$

$\begin{array}{ll}\text { Employer } & 5\end{array}$

$\begin{array}{ll}\text { Employer Safety Program and Training } & 5\end{array}$

$\begin{array}{ll}\text { Victim } & 5\end{array}$

$\begin{array}{lc}\text { Equipment } & 6\end{array}$

$\begin{array}{lr}\text { Incident Scene } & 6\end{array}$

$\begin{array}{lr}\text { Weather } & 6\end{array}$

$\begin{array}{lc}\text { INVESTIGATION } & 6\end{array}$

$\begin{array}{lr}\text { CAUSE OF DEATH } & 10\end{array}$

$\begin{array}{lr}\text { CONTRIBUTING FACTORS } & 10\end{array}$

$\begin{array}{ll}\text { RECOMMENDATIONS AND DISCUSSION } & 11\end{array}$

$\begin{array}{ll}\text { REFERENCES } & 16\end{array}$

$\begin{array}{ll}\text { INVESTIGATOR INFORMATION } & 17\end{array}$

$\begin{array}{ll}\text { FACE PROGRAM INFORMATION } & 17\end{array}$

$\begin{array}{ll}\text { ACKNOWLEDGMENTS } & 18\end{array}$ 


\section{SUMMARY}

In February of 2011, a 39-year-old truck driver working outside his semi-trailer truck died when he was struck and crushed against his trailer by a semi-trailer truck that swung wide as it pulled out of an adjacent parking stall. The victim was employed by a general freight trucking company that transports refrigerated goods. He had 10 years' experience driving semi-trailer trucks.

On the day of the incident, the victim was assigned by his dispatcher to pick up freight consisting of a full trailer load of chilled boxed beef at a customer's meat processing facility. The victim drove his truck to the customer location. He then drove to the empty trailer lot portion of the yard where he unhooked and dropped his refrigeration trailer. An employee of the facility hooked the trailer to a yard hostler and hauled it to the loading dock to be loaded with freight.

After the trailer was loaded, the hostler operator deposited the trailer in the loaded trailer lot. Located across from the loading dock, the lot's surface is a mixture of asphalt and concrete with yellow lines marking the parking stalls. There are often several trailers parked in the lot. It is a part of the yard where loaded trailers are left awaiting their drivers who then back their trucks up to their trailers and hook them up and prepare for departure. Drivers may pick-up their trailers at any time during the day or night.

The victim backed his truck up to his trailer and hooked it up. As he was doing this and preparing to depart, he chatted with the driver of a truck in the adjacent parking stall who was also preparing to depart. The driver of the other truck finished his pre-trip check and got into the cab of his truck. He reported that he last saw the victim standing at the rear of his own truck's trailer. Less than a minute after last seeing the victim the other driver checked his mirrors and started moving the truck forward out of the stall.

As he drove forward he made a sharp turn to the left in order to avoid a hostler parked in front of his truck. The victim was standing on the driver's side of his trailer near the front cranking up his trailer's landing gear. It was dark and he was not wearing the high-visibility safety vest which his employer had issued him. As the other truck moved forward and swung left the right rear of its trailer struck the victim. The driver was not aware that the victim had been struck and proceeded to leave the yard. The victim died at the scene. 


\section{RECOMMENDATIONS}

To prevent similar occurrences in the future, Washington State Fatality Assessment and Control Evaluation (FACE) investigators concluded that to protect employees from the hazard of being struck by a moving truck while working outside of their truck in parking, and freight loading/unloading areas employers and facility owners should follow these guidelines:

- Perform a site survey of facilities with truck loading and unloading areas, parking areas, and yards where there is truck traffic to identify potential truck vs. pedestrian hazards and take corrective actions to prevent pedestrians being struck by trucks.

- Design site layout of facilities and internal truck traffic routes to provide adequate space for trucks to safely maneuver, load, unload, and park. Facility design should also provide for safe passage for pedestrians. The level of lighting should be sufficient for safe vehicle and pedestrian activity.

- Host facilities should create and enforce a policy requiring drivers to wear a highvisibility safety vest when outside their vehicle.

- Train drivers to initiate and maintain communication with other drivers when working outside their truck in parking, loading, and unloading areas so as to ensure that their activities do not put them at risk of being struck by the movement of other trucks.

- Provide truck drivers with appropriate high-visibility safety vests and train them to ensure that they are worn in an effective manner whenever they exit their vehicle.

- Install appropriate mirrors on all fleet trucks to ensure that drivers have superior visibility and that blind spots on the right side of the vehicle are eliminated.

- Truck manufacturers, equipment designers, and researchers should continue to develop onboard systems and equipment that allow truck drivers to better detect pedestrians. 


\section{INTRODUCTION}

In February of 2011, the Washington FACE Program was notified by the Washington State Department of Labor and Industries Division of Occupational Safety and Health (DOSH) of the death of a 39-year-old truck driver. The victim, an employee of a trucking company, was on-foot at a customer yard preparing his loaded semi-trailer truck for departure. Another truck parked next to the victim began to depart. As this truck was pulling out of the parking stall, it swung wide and its trailer struck the victim who was raising the landing gear on the driver's side of his truck. The victim died at the scene.

In January of 2013, Washington State FACE investigators visited the employer's headquarters office and interviewed the manager responsible for driver safety compliance and training. The investigators reviewed documents which included the victim's death certificate, police report, and the DOSH investigation file.

\section{Employer}

The employer is a subsidiary of a general freight trucking company that has been in business since 1972. They haul primarily refrigerated goods for customers located predominately in the Western U.S. The company is headquartered in Washington State. At the time of the incident, the company employed 130 full-time drivers. Their long-haul truck drivers are typically on the road for two to three weeks at a time.

\section{Employer Safety Program and Training}

The employer had a formal, written Accident Prevention Program (APP), as required by law in Washington State. There is a full-time safety manager and four training facilitators. All new hires attend a four day safety orientation class. This orientation consists of safety videos, a road test, drug screen, defensive driving course, written quizzes, and physical capacity testing. Hands-on training is provided to ensure that the new hires know how to operate the company refrigeration unit trucks that they will be required to drive. Annual refresher classes are provided for all employees. There is a joint employer and employee safety and health committee. Safety meetings are held monthly. If drivers are at the headquarters they will attend the safety meetings, otherwise the employer sends out safety messages by satellite to drivers who are on the road. Due to the nature of their work which keeps them on the road for extended periods, satellite messaging is the primary medium of communication that the employer uses to send safety messages to their drivers.

\section{Victim}

The 39-year-old truck driver had worked for the employer for just over a month. Previously, he had driven refrigeration unit trucks for 10 years. His job duties included driving a truck with a refrigeration unit semi-trailer. He made pickups and deliveries of freight for customers in the Western U.S. He had 
a class "A" commercial driver's license (CDL). This was his first freight pickup at the customer yard incident site.

\section{Equipment}

The victim's semi-trailer truck was a Peterbilt with a refrigeration, or reefer, unit trailer. The victim was struck by a semi-trailer truck of an unknown model and make.

\section{Incident Site}

The incident took place in the loaded trailer lot portion of the yard of a meat processing facility. Truck drivers picking up freight leave their trailers at the empty trailer lot portion of the yard. A yard hostler, also known as a yard goat, will then haul the trailer to the loading dock where the trailer is loaded with freight. The hostler then deposits the loaded trailer at the loaded trailer lot of the yard. The truck driver then hooks up the truck to the trailer and prepares for departure. This facility operates around the clock with trucks continually arriving and departing from the yard.

At the time of the incident, it was dark. The area near the loaded trailer lot was illuminated by several lights placed on a nearby building.

\section{Weather}

At the time of the incident, there were scattered clouds with a temperature of 37 degrees Fahrenheit. ${ }^{1}$

\section{INVESTIGATION}

On the day of the incident, the victim had returned to work after three days off. He was assigned by his employer's dispatcher to pick up freight consisting of a full trailer load of chilled boxed beef at a customer meat processing facility and deliver it to another customer location in California. The victim drove his semi-trailer truck with an empty refrigeration trailer from his employer's yard to the customer freight pick-up location. The trip was about 190 miles and took about 3 hours. After checking in with the guard at the security station, he drove onto the grounds of the customer's meat processing facility. He then drove through the yard to the empty trailer lot, where he dropped his trailer. An employee of the facility hooked the trailer to a yard hostler and hauled it to the loading dock to be loaded with freight.

It is unknown where the victim was during the loading process. According to the employer's safety manager, drivers take their trucks to another part of the yard where they park and then may take a nap in their truck or drive off-site. 
After the trailer was loaded, the hostler operator deposited the trailer in the loaded trailer lot. Located across from the loading dock, the lot's surface is a mixture of asphalt and concrete with yellow lines marking the parking stalls. There are often several trailers parked in the lot. It is a part of the yard where loaded trailers are left awaiting their drivers who then back their trucks up to their trailers and hook them up and prepare for departure. Drivers may pick-up their trailers at any time.

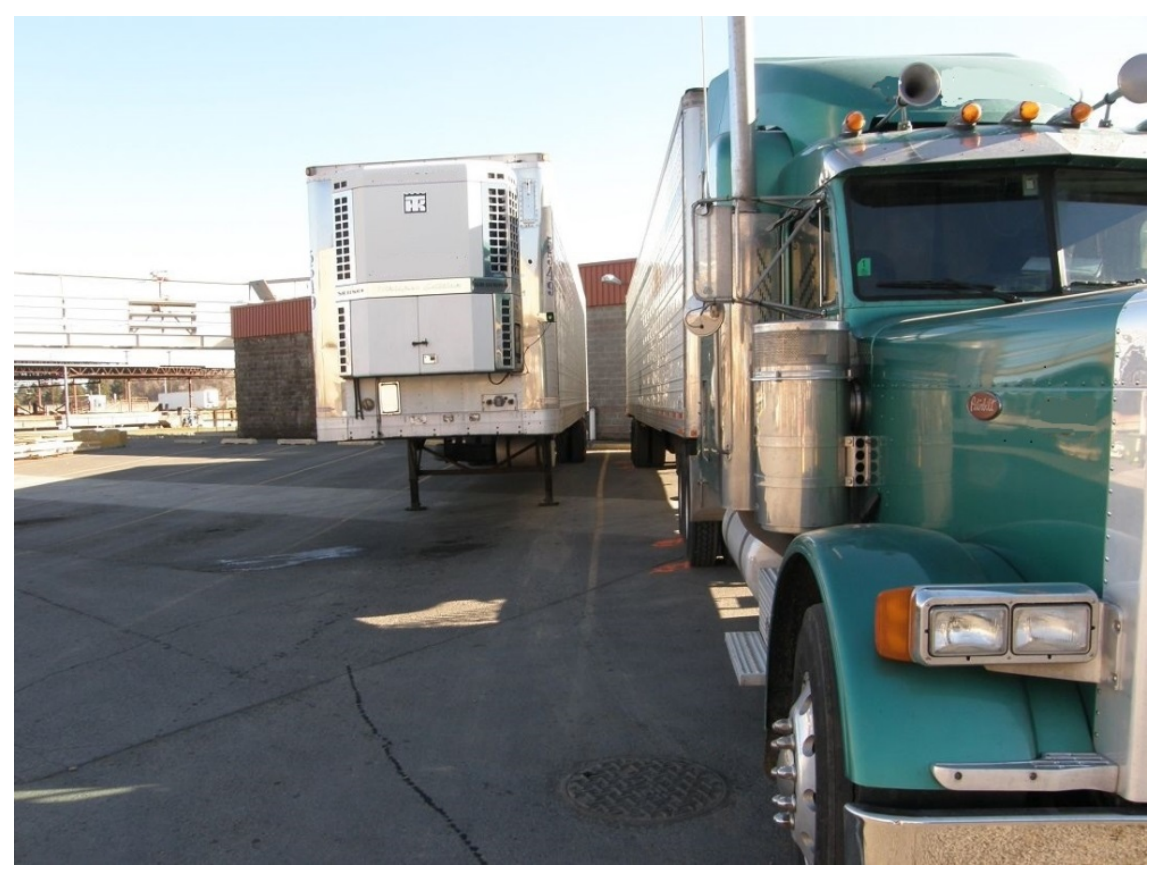

\section{Photo 1: Loaded trailer lot with refrigeration unit trailer waiting to be hooked-up to a truck next to the victim's semi-trailer truck.}

At 6:25 p.m., an employee of another carrier drove his truck past the security guard station in the direction of the trailer he was there to pick up, followed by the victim's truck a few seconds later. The other truck driver began to back his truck under the loaded trailer while the victim waited. The victim then drove past him and backed up to his trailer which was in the stall to the right of the other truck. The distance between the two parked trucks was approximately 40 inches.

The driver of the other truck was an experienced driver, having driven trucks for over thirty years. He was team driving with his partner who was in the passenger seat of the truck's cab. This was the second time that he had made a pick up at this location since he had started working with his employer, a trucking company, the previous year.

The victim and the other truck driver stepped out of their trucks and chatted with each other as they hooked up their trailers to their trucks. They then both did their pre-trip safety checks by walking around their trucks. The driver of the other truck finished his pre-trip check and got into the cab of his truck. He reported that the last time he saw the victim he was standing at the rear of his own truck's trailer. A high-visibility safety vest had been issued to the victim by the employer, but he was not wearing it at this time. The vest was in the truck's cab. 
The other driver started his engine, released his air brakes, checked his mirrors, and at 6:37 p.m. began pulling out of the stall. The driver reported that it was about 30-45 seconds between when he last saw the victim and when he started moving his truck. As he moved forward, he made a sharp left turn to avoid a yard hostler temporarily parked in the loading dock area in front of him. (See figure 1).

The victim was standing beside his trailer on its left side near the front cranking up his trailer's landing gear as the other truck left the stall. As the other truck moved forward and swung left the right rear of its trailer struck the victim. The driver and his co-driver were unaware that the victim had been struck. They then proceeded to leave the yard and continue down the road.

At 6:49 p.m., a truck driver drove into the yard and saw the victim lying on the ground beside the landing gear of his trailer. He got out of his truck and checked the victim's pulse and found him to be deceased. He then ran to the facility's guard station and notified the guard. The guard called 911. At 6:56 p.m. emergency services personnel began arriving at the site. He was pronounced dead at the scene.

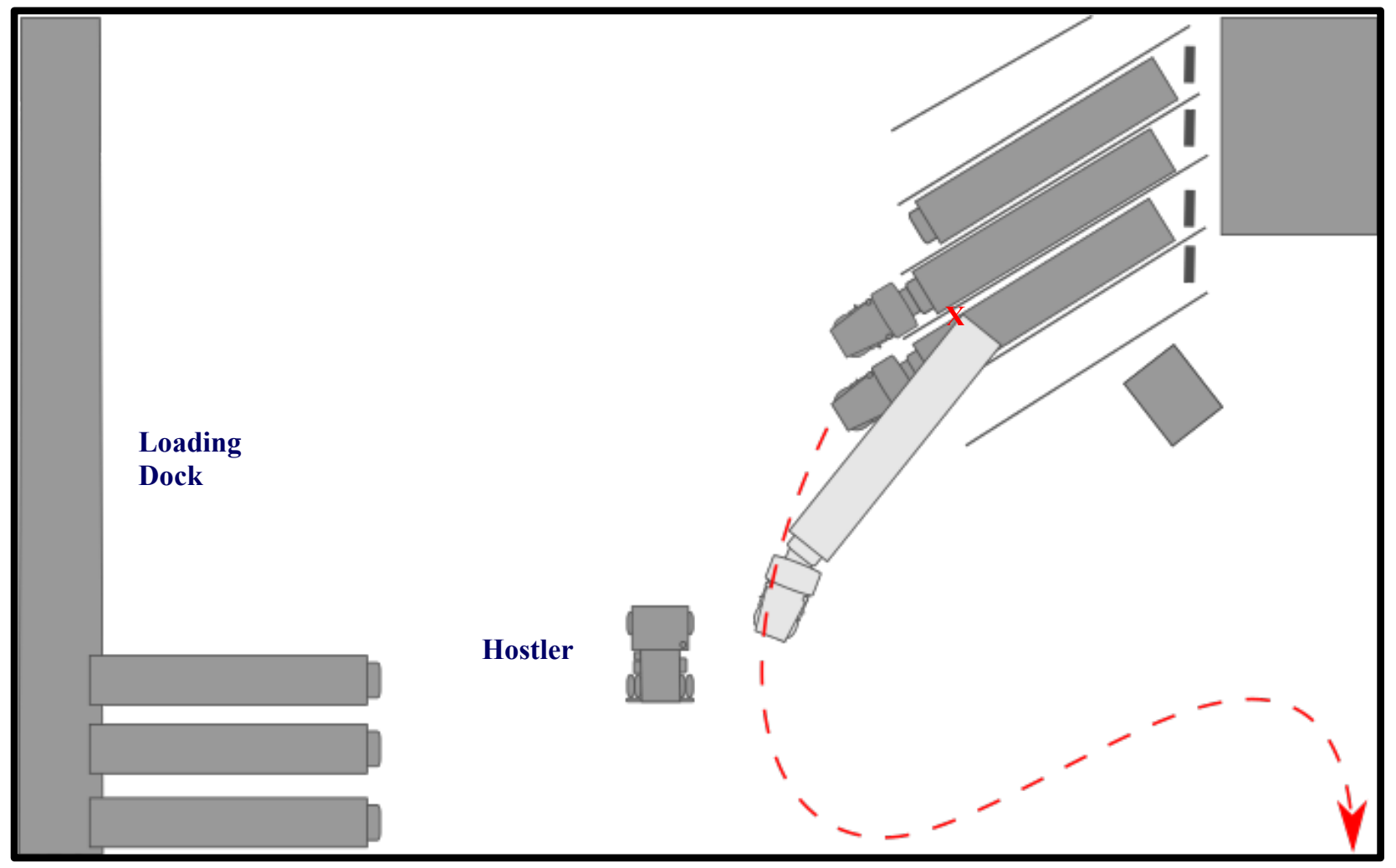

Figure 1. Customer truck yard and loading dock area where the incident occurred. The " $X$ " indicates the victim's approximate location when he was struck by the right rear of the departing truck's trailer. The dotted line indicates the semi-trailer truck's approximate path of travel as it exited the parking stall. (Not to scale) 


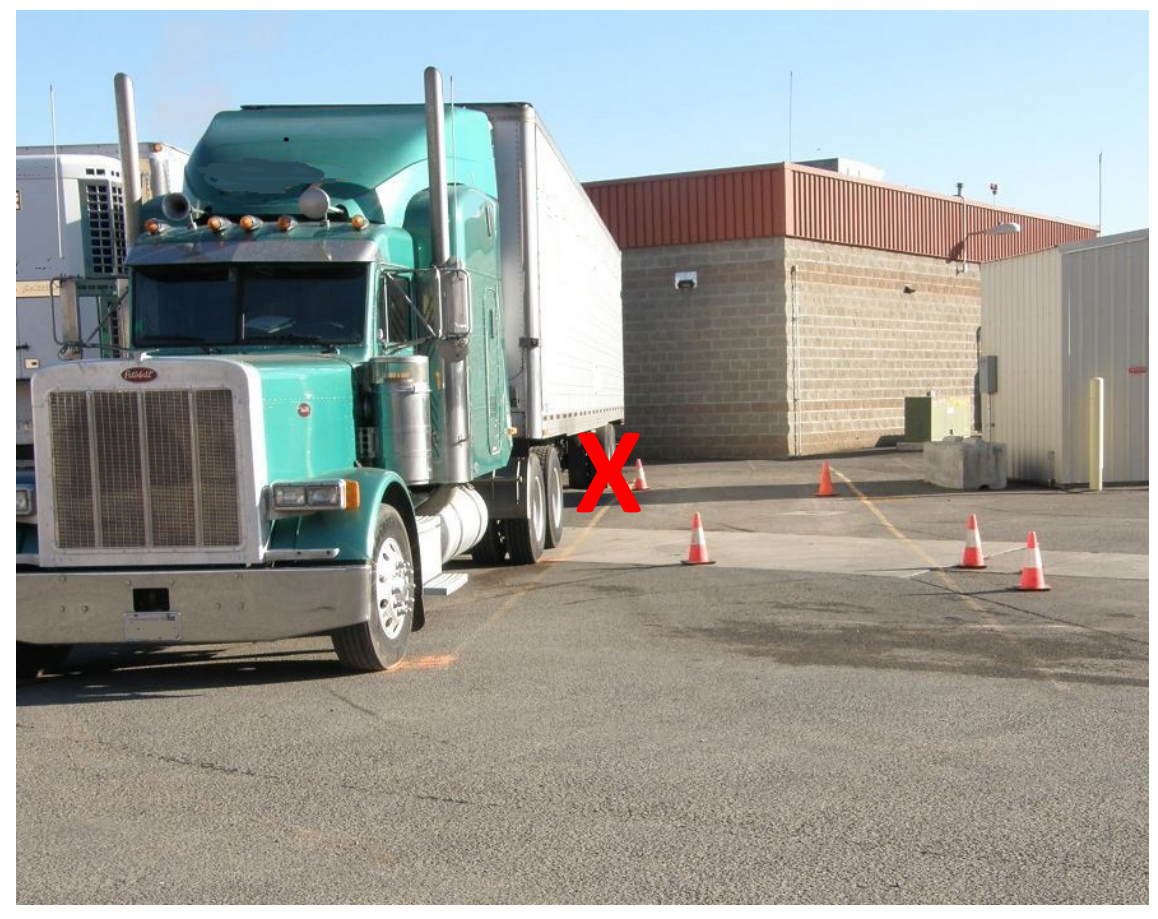

Photo 2: Incident scene showing the victim's semi-trailer truck and the adjacent parking stall where the semi-trailer truck was parked before it pulled out and its trailer struck the victim. The two trailers may have created a shadowy area and low-light condition between the two parked semi-trailer trucks which may have made it difficult to be seen by either the driver or co-driver passenger from the adjacent truck's cab. The " $X$ " marks the victim's approximate location.

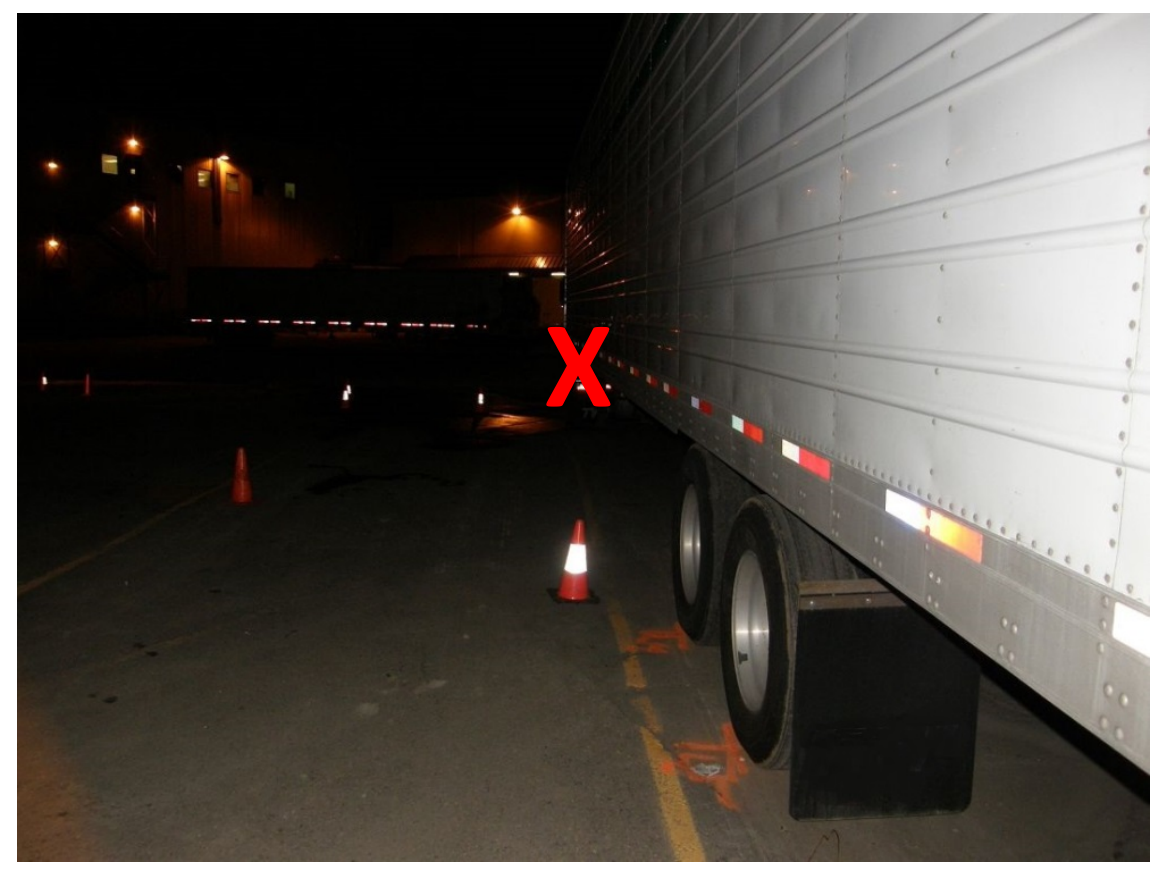

Photo 3: Incident scene at night. The view is from the left rear of the victim's trailer looking toward the loading dock area. The light in the foreground was supplied by camera flash. The approximate location of the victim is marked by the " $X$ ". 


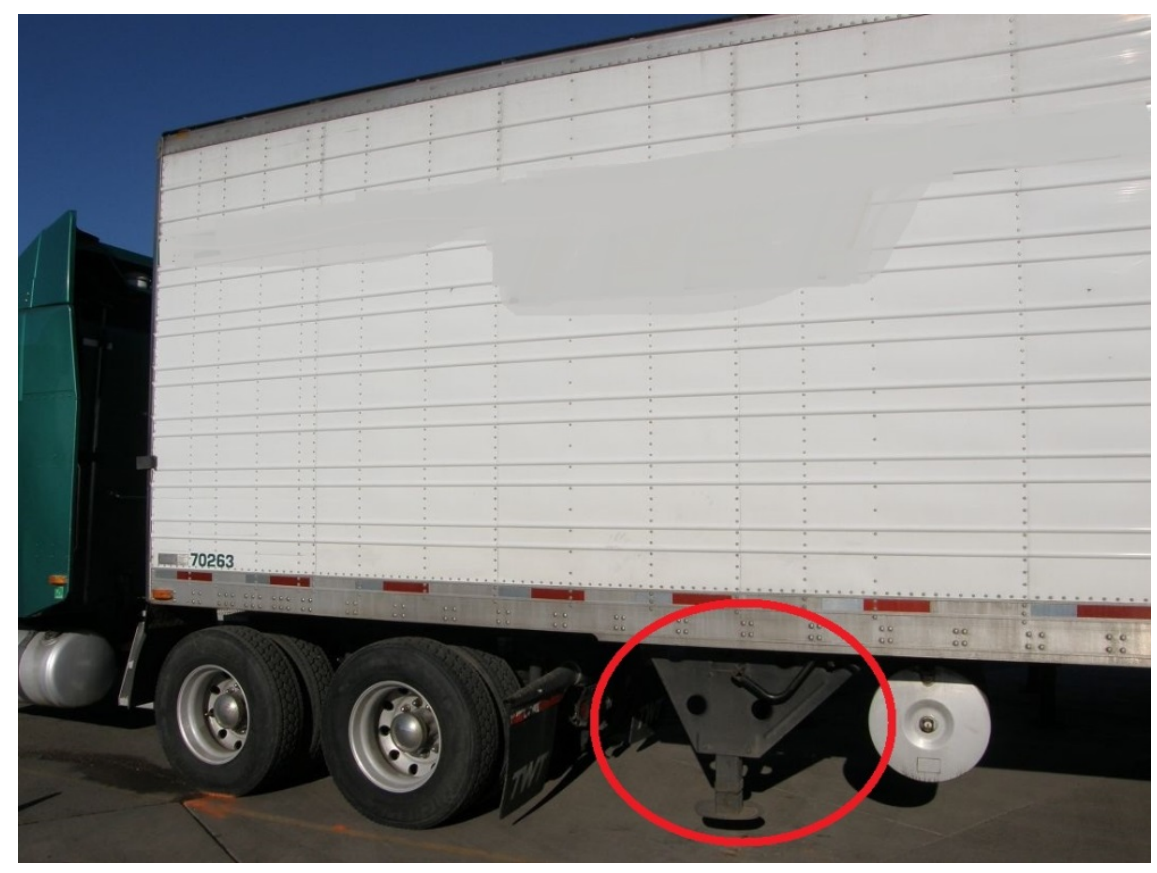

Photo 4: Landing gear that the victim was cranking up when he was struck by the departing semi-trailer truck.

\section{Cause of Death}

According to the death certificate, the coroner reported the cause of death as "multiple internal injuries due to massive head and trunk trauma due to motor vehicle pedestrian accident."

\section{CONTRIBUTING FACTORS}

Occupational injuries and fatalities are often the result of one or more contributing factors or key events in a larger sequence of events that ultimately result in the injury or fatality. Washington FACE investigators identified the following factors that may have contributed to the death of the truck driver:

- Failure of the drivers to communicate with each other about their activities.

- Victim was not wearing a high-visibility safety vest.

- Lack of site policy requiring drivers to wear high-visibility vests.

- Lot design and width of parking spaces.

- Location of hostler.

- Lighting and visibility at night. 


\section{RECOMMENDATIONS AND DISCUSSION}

Recommendation \#1: Perform a site survey of facilities with truck loading and unloading areas, parking areas, and yards where there is truck traffic to identify potential truck vs. pedestrian hazards.

Discussion: Owners of facilities where truck traffic occurs should survey their yards and loading dock areas to assess the risk of pedestrians and workers on-foot to the hazard of being struck by moving trucks. This site survey could include an assessment of the layout of truck traffic flow, site traffic control, lighting, driver visibility (especially under low-light conditions), pedestrian marked or segregated walking areas, parking areas, trailer lots, and other areas and potential conditions that may affect pedestrian safety.

Recommendation \#2: Take corrective actions to prevent pedestrians from being struck by trucks. Design site layout of yards and internal truck traffic routes to provide adequate space for trucks to safely maneuver, load, unload, and park. Facility design should also provide for safe passage for pedestrians. The level of lighting should be sufficient for safe vehicle and pedestrian activity.

Discussion: The design of yards should take into account the safety of pedestrians and workers onfoot. There should be adequate space for the movement of vehicles and the safe passage of pedestrians. Truck traffic flow through the yard should be planned and designated so that trucks will be able to move smoothly and without obstructions.

Traffic flow management at the loading dock and yard should be considered so that drivers entering and departing can safely maneuver without having to take evasive actions to avoid parked vehicles and yard equipment.

Adequate area lighting for loading docks and truck yards should be planned and provided, not only to allow workers to successfully complete their tasks, but for their safety as well. Current lighting should be assessed to determine whether it is suitable and safe for the type of work being done.

Consideration should be given to consulting with a lighting manufacturer or an engineering firm that can assist with the design and/or retrofit of lighting fixtures.

It is uncertain whether in this incident facility lighting was a factor in providing enough luminance for the victim to be visible to the departing driver. The two trailers may have created a shadowy area between the two parked semi-trailer trucks, creating a low-light condition which may have made it difficult to be seen by either the driver or co-driver passenger from the adjacent truck's cab.

Placement of yard lighting should take into account the nature of the changing conditions of the working environment in the yard. Parked trucks and their trailers can create light obstructions that reduce the amount of light from lighting fixtures and impair the visibility of pedestrians and workers on-foot to drivers of trucks as they move about the yard. ${ }^{7,8}$ 


\section{Recommendation \#3: Employers and host facilities should create and enforce policies requiring drivers to wear a high-visibility safety vest when outside their vehicle.}

Discussion: Requiring drivers to wear high-visibility safety vests whenever they leave their vehicle's cab, both during daylight and nighttime hours, will increase their visibility to operators of motor vehicles and mobile equipment. Host facilities should communicate their safety policy regarding the wearing of high-visibility safety vests on their facilities to the visiting drivers' employer before drivers arrive at the site. Upon arrival at the host facility this policy should also be communicated to visiting drivers verbally and/or by signage.

Recommendation \#4: Train drivers to initiate and maintain communication with other drivers when working outside their truck in parking, loading, and unloading areas so as to ensure that their activities do not put them at risk of being struck by the movement of other trucks.

Discussion: Employers should train drivers to communicate with other drivers when they are outside their truck. Employers should also train drivers to ensure that other drivers and workers on-foot are inthe-clear of trucks before moving. Drivers should:

- Communicate with other drivers and pedestrians during their pre-trip safety check and prior to moving their truck.

- Honk the truck's horn before moving to alert drivers and other personnel who may be working or walking nearby.

- Use a spotter to guide them out of tight spaces or when visibility is poor.

Recommendation \#5: Employers should provide truck drivers with appropriate high-visibility safety vests and train them to ensure that they are worn in an effective manner whenever they exit their vehicle.

Discussion: Employers should emphasize through training to their drivers the importance of wearing their high-visibility vest whenever they step outside their truck, both day and night. For their safety, drivers need to be seen when walking and working outside their trucks. According to ANSI/ISEA 1072010 American National Standard for High-Visibility Safety Apparel and Headwear:

Low visibility is a serious hazard for workers who must perform tasks near moving vehicles or equipment. Workers must be visible to vehicle operators in all lighting conditions and against complex environmental backgrounds. The sooner a vehicle operator sees a pedestrian worker, the longer the operator has to avoid an incident. High-visibility personal protective equipment (PPE) dramatically enhances worker safety. ${ }^{2}$

According to the employer's safety manager, prior to the incident they had issued all drivers highvisibility safety vests. The victim had one of these vests, but he was not wearing it; it was in his truck's cab. Their policy at that time was that drivers should put on a vest when they were outside their cab in traffic areas during chaining up alongside a road and walking around yards with forklifts and trucks moving about. After the incident, the employer requires its drivers to wear a high-visibility vest whenever they get out of their truck. 
The ANSI/ISEA standard specifies three classes of high-visibility garments based on the wearer's activities and exposure to traffic hazards. A class 1 garment has the minimum amount of material to differentiate the wearer from the work environment. A class 2 garment provides additional visibility. A class 3 garment offers the highest level of visibility.

It is recommended that at least a class 2 high-visibility vest should be worn by truck drivers. Additionally, employers should consider issuing LED headlamps/flashlights to drivers to use so as to make them visible to others when they are working outside their vehicles in dark or low light conditions.

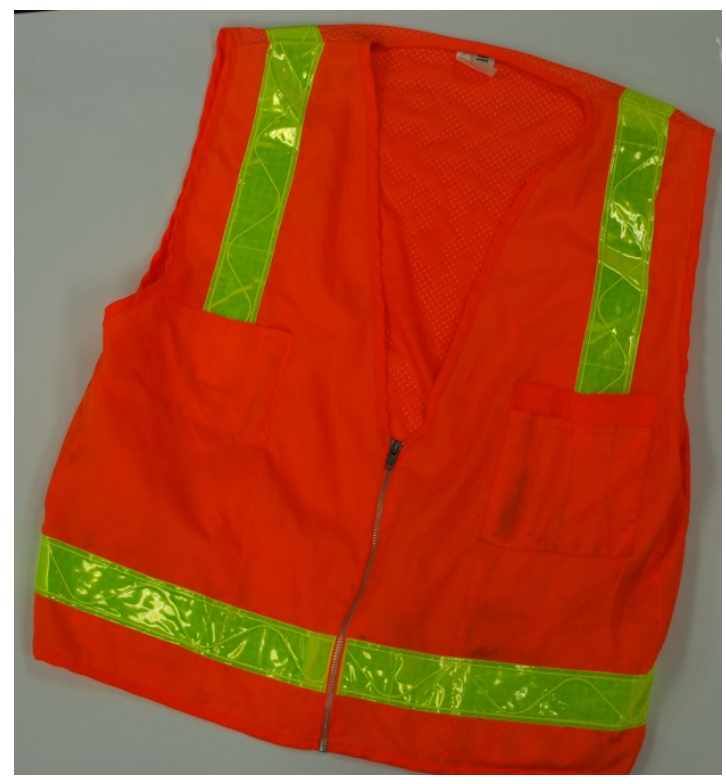

Photo 5: Example of class 2 safety vest.

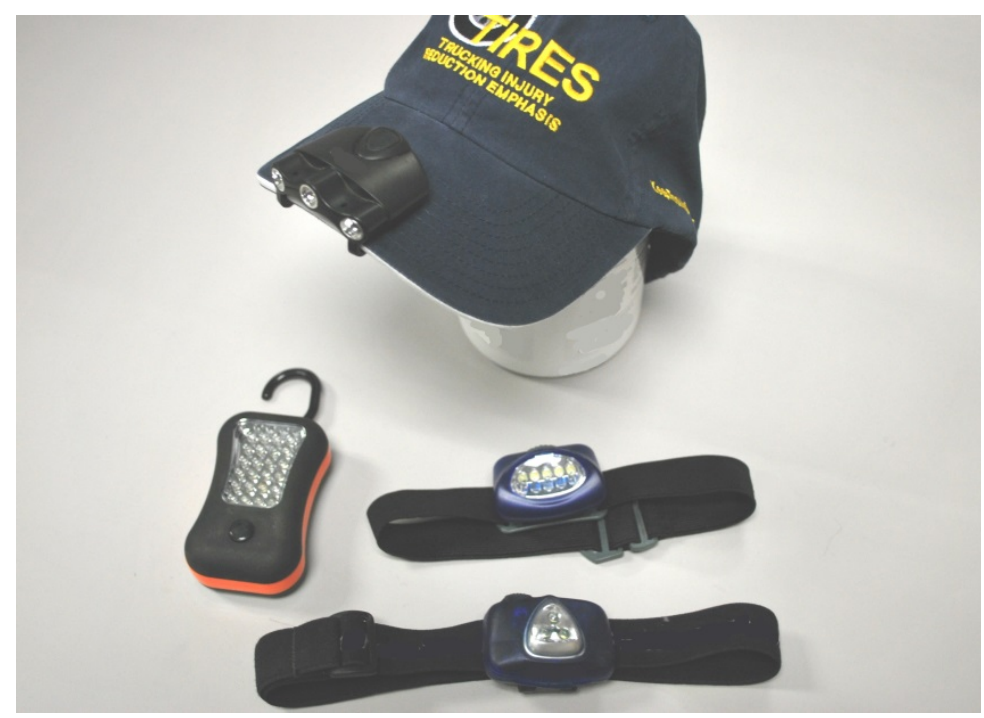

Photo 6: The use of a headlamp or flashlight by a driver while walking or working outside their vehicle will provide illumination that will help them to be noticed by truck or other vehicle operators. 
Recommendation \#6: Install appropriate mirrors on all fleet trucks to ensure that drivers have superior visibility and that blind spots on the right side of the tractor-trailer are eliminated.

Discussion: Research has shown that "measurements of truck driver fields of view show reduced field of view along the right side of the truck, especially on the right front of the vehicle if there is no fender/hood mounted mirror." 11

Installing convex mirrors on the hood or fender of the truck will increase the driver's field of view along the sides of the truck and trailer and help them to see objects and pedestrians.

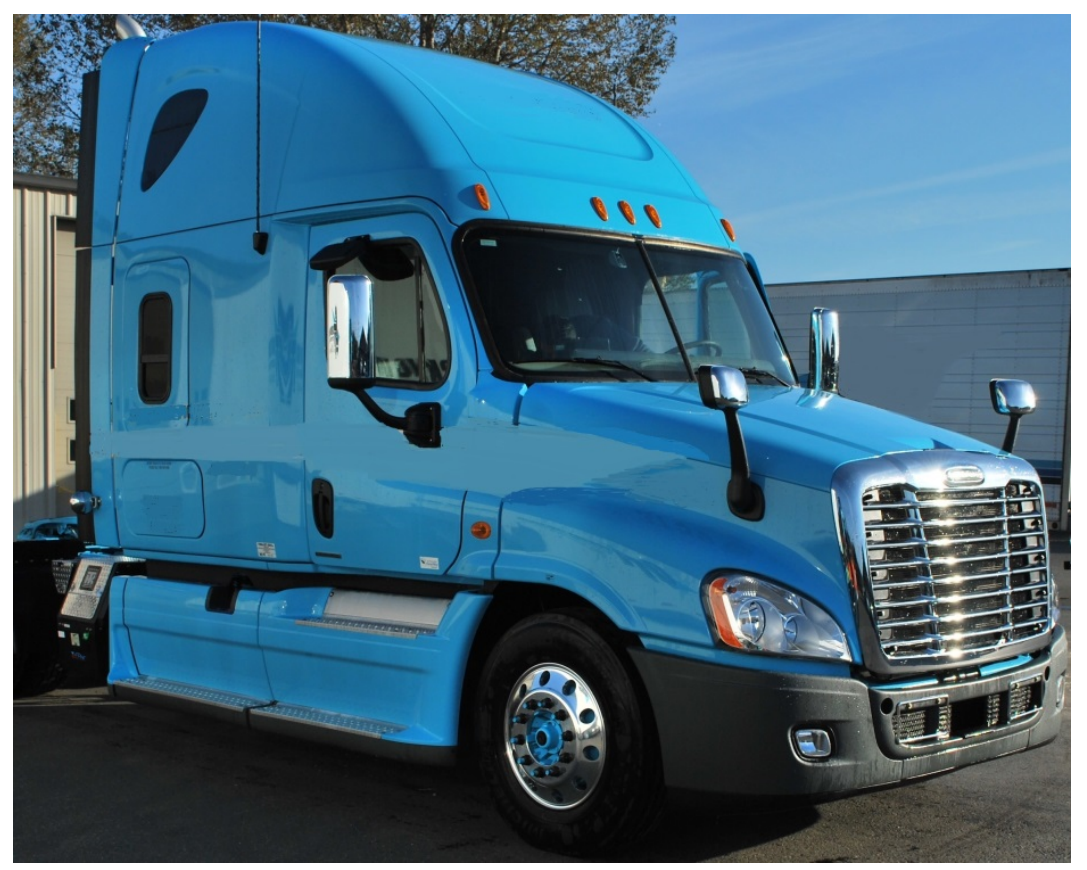

Photo 6: Hood-mounted convex mirrors extend the driver's field of view along the sides of the truck and trailer.

Recommendation \#7: Truck manufacturers, equipment designers, and researchers should continue to develop onboard systems and equipment that allow truck drivers to better detect pedestrians.

Discussion: Both the National Transportation Safety Board (NTSB) ${ }^{9}$ and the American Trucking Associations' (ATA) ${ }^{10}$ Technology and Maintenance Council have recommended that technology and equipment be developed and deployed to increase truck drivers' knowledge of what is around their vehicles, including pedestrians, so that safety can be improved.

The NTSB in its recommendation to the National Highway Traffic Safety Administration (NHTSA) stated: 
“...onboard systems and equipment that can allow the tractor-trailer drivers to better detect passenger vehicles, motorcyclist, pedestrians, and cyclists are available and that the use of such systems could prevent fatalities and injuries that occur in collisions involving tractortrailers. The NTSB recommends that NHTSA require that newly manufactured truck-tractors with GWWR over 26,000 pounds be equipped with visibility enhancement systems to improve the ability of drivers of tractor-trailers to detect passenger vehicles and vulnerable road users, including pedestrians..." 


\section{REFERENCES}

1. Weather Underground.

http://www.wunderground.com/history/airport/KYKM/2011/2/19/DailyHistory.html?req city=Toppenish \&req state=WA\&req statename $=$ Washington $\& M R=1$

2. American National Standards Institute/International Safety Equipment Association (2010).

ANSI/ISEA 107-2010 - American National Standard for High-Visibility Safety Apparel and Headwear. http://webstore.ansi.org/RecordDetail.aspx?sku=ANSI\%2FISEA\%20107-

2010\&source=google\&adgroup=ansi-isea\&gclid=CNbzw5a4xsQCFQiVfgod4oQAXQ

3. Trucking Injury Reduction Emphasis (TIRES). Tip Sheet: Be Seen, Be Safe. SHARP Program, Washington State Department of Labor and Industries.

http://www.keeptruckingsafe.org/safetymaterials/90292009.pdf

4. Trucking Injury Reduction Emphasis (TIRES). True Stories: "Let's Make Sure This Doesn't Happen Again." SHARP Program, Washington State Department of Labor and Industries.

http://www.keeptruckingsafe.org/safetymaterials/901132013.pdf

5. Trucking Injury Reduction Emphasis (TIRES). Poster: "Camo is Not Part of this Job Description." SHARP Program, Washington State Department of Labor and Industries.

http://www.keeptruckingsafe.org/safetymaterials/901082013.pdf

6. Trucking Injury Reduction Emphasis (TIRES). True Stories: Driver Killed When Run-over by CoWorker." SHARP Program, Washington State Department of Labor and Industries.

http://www.keeptruckingsafe.org/safetymaterials/90232008.pdf

7. Boyce, Peter R. (2003). Human Factors in Lighting. Taylor and Francis, New York, NY.

8. Health and Safety Executive (1997). Lighting at Work.

http://www.hse.gov.uk/pubns/priced/hsg38.pdf

9. National Transportation Safety Board. (2014). Safety Recommendations.

http://www.ntsb.gov/safety/safety-recs/RecLetters/H-14-001-007.pdf

10. Technology and Maintenance Council (2015). Future Truck Program Position Paper: 2015-1.

American Trucking Associations.

http://www.trucking.org/ATA\%20Docs/About/Organization/TMC/Documents/Position\%20Papers/Futur e\%20Truck\%20Position\%20Papers/FT PP 2015 01.pdf

11. Blower, Daniel F. (2007). Truck Mirrors, Fields of View and Serious Truck Crashes. UMTRI-200725. Ann Arbor, Michigan, University of Michigan Transportation Research Institute.

http://deepblue.lib.umich.edu/bitstream/handle/2027.42/58728/99830.pdf?sequence=1 


\section{Investigator Information}

Todd Schoonover has a PhD in Industrial Hygiene from the University of Illinois at Chicago. He is a Certified Industrial Hygienist $(\mathrm{CIH})$ and Certified Safety Professional (CSP). Todd is currently the Principle Investigator for the WA FACE Program.

Christina Rappin has a BAS from The Evergreen State College. She is a Research Investigator with the WA FACE program.

Randy Clark has a BA from the Evergreen State College. He is a Safety and Health Specialist with the WA FACE Program.

Washington State FACE Program Information

The Washington State Fatality Assessment and Control (WA FACE) program is one of many workplace health and safety programs administered by the Washington State Department of Labor \& Industries' Safety \& Health \& Research for Prevention (SHARP) program. It is a research program designed to identify and study fatal occupational injuries. Under a cooperative agreement with the National Institute for Occupational Safety and Health (NIOSH grant\# 5 U60 OH008487-11), WA FACE collects information on occupational fatalities in WA State and targets specific types of fatalities for evaluation. WA FACE investigators evaluate information from multiple sources. Findings are summarized in narrative reports that include recommendations for preventing similar events in the future. These recommendations are distributed to employers, workers, and other organizations interested in promoting workplace safety. NIOSH-funded, state-based FACE programs include: California, Kentucky, Massachusetts, Michigan, New York, Oregon, and Washington. WA FACE does not determine fault or legal liability associated with a fatal incident. Names of employers, victims and/or witnesses are not included in written investigative reports or other databases to protect the confidentiality of those who voluntarily participate in the program.

Additional information regarding the WA FACE program can be obtained from:

Washington State FACE Program

www.Ini.wa.gov/Safety/Research/FACE/default.asp

PO Box 44330

Olympia, WA 98504-4330

1-888-667-4277 


\section{ACKNOWLEDGMENTS}

This report was reviewed by stakeholders from labor and business communities and various Washington State and Federal worker safety agencies. Though we are unable to acknowledge specific individuals for their contributions to this report, we would like to recognize the following for their help and support of the FACE mission and objectives:

- The employer's representatives

- Division of Occupational Safety and Health (DOSH)

- Federal FACE Program management (NIOSH)

- Safety \& Health Assessment \& Research for Prevention (SHARP) 